\title{
IN THE MIDST OF THE LARGE DAM CONTROVERSY: OBJECTIVES, CRITERIA FOR ASSESSING LARGE WATER STORAGES IN THE DEVELOPING WORLD
}

\author{
Zankhana Shah ${ }^{1}$ and M. Dinesh Kumar ${ }^{2}$
}

\begin{abstract}
By some estimates, there are 47,000 large dams in the world. India had 4,635 "large dams" as per ICOLD definition. Only technical criteria such as height and storage volume are used for this classification. Large dam projects increasingly face opposition from the environmental lobby from around the world for their negative social and environmental impacts, while their role in development was largely ignored. There are two issues being investigated in this paper. First: what should be the best criterion for classifying dams in a way that they truly reflect the engineering, social and environmental challenges posed by dams? Second: what new objectives and criteria, and variables need to be incorporated in the cost-benefit analysis of dams so as to make it comprehensive?

The analysis based on data of 13,631 large dams across the world shows that the height of the dam does not have any bearing on the volume of water stored, a strong indicator of the safety hazard posed by dams. Further analysis using data of 9,878 large dams shows that the height has no bearing on the area of land submerged, again an indicator of the negative social and environmental effects. The regression using data on 156 large dams across India shows that normative relationship exists between the area of submergence and numbers of people displaced by dams. Therefore, a combination of criteria such as height, storage volume and the area under submergence needs to be considered for assessing the negative social and environmental consequences of dams. Further analysis shows that the available estimates of dam displacement could be "gross over-estimates" in the order of magnitude of eight.

By illustrating the significant positive impact of large reservoir project on stabilizing national food prices, contributing clean energy, improving recharge to groundwater in semi arid and arid regions, and ensuring social security, the authors argue that economic viability of these projects should be assessed in relation these positive externalities they create. The authors estimate the benefit due to lower food prices attributed to large dams in India as Rs. 42.90 billion annually. At the same time, the negative externality effects of large dams should be built in the cost of dam projects to increase the accountability on the part of water development agencies in less developed countries, towards the communities, which are adversely affected by large dams.
\end{abstract}

\section{INTRODUCTION}

The current crisis and urgency of meeting the food water requirements of the burgeoning world population has further aggravated the debate on 'Dams or No Dams'. The greatest opposition which dams builders from around the world face is on environmental (see for instance, D'Souza, 2002 and McCully, 1996), financial, economic, and human rights front (see for instance Dharmadhikary, 2005; Fisher, 2001 and McCully, 1996), whereas the proponents of large dam push their agenda on the grounds of enhanced food and drinking water security, hydropower generation, and flood control (see Braga et al., 1998; Verghese, 2001; Vyas, 2001).

In the later half of $19^{\text {th }}$ century, the move of large dam construction started in the developed countries holding technical know-how and financial resources and later spread to the developing countries. By 1975, when the United States, Canada and the Western European countries had essentially completed their programme of construction of large dams (Biswas and Tortajada, 2001), majority of the developing countries were either

\footnotetext{
${ }^{1}$ Consultant, International Water Management Institute, South Asia Sub-regional Office, Patancheru, AP, India. Email: shahzank@gmail.com

${ }^{2}$ Researcher and ITP Leader, International Water Management Institute, South Asia Sub-Regional Office, Patancheru, AP, India. Email: d.kumar@cgiar.org
} 
on their peak of dam construction or were just starting to divert their financial resources towards it. As per the data offered by International Commission on Large Dams (ICOLD) in World Register of Large Dams (2003), at the end of the $20^{\text {th }}$ century, China and India kept the United States far behind in total numbers of dams constructed.

According to the data, there are more than 47,000 large dams constructed all over the world and another 1700 dams were under construction. But, the statistics of large dams presented by ICOLD is based on the widely accepted and uniform definition, which considers dam height as the sole criterion. While it is widely quoted that Asia has largest number of large dams in the world, it is silent on how much water is being stored in these dams, and how much area they submerge. According to a World Commission of Dams (WCD) database, dated 2000, China has the largest number of large dams, followed by rest of Asia, immediately followed by North and Central America. But, global comparisons provided by ICOLD register on large dams dated 1998 on the basis of the volume of storage created by large dams brings out a totally different picture. Nearly $29 \%$ of the total storage from large dams $\left(6,464 \mathrm{~km}^{3}\right)$ is in North America, followed by South America (16\%). China (10\%) is only $4^{\text {th }}$ in terms of volume of storage. Lack of comprehensive criteria for defining "large dams" makes such statistics misleading. But, the criteria of evaluating dam performance should change with the objectives.

Limitations are also inherent in the methods used for benefit-cost analysis. The methods identify only those costs and benefits which can be assigned a market value. Like many social and environment costs are not considered due to limitations in assigning them economic value, many real benefits are underestimated or unenvisaged at the time of project planning. For example, a water resource planning exercise done in the Indian state of Gujarat has checked the possibilities and recommended the use of water from Sardar Sarovar Project (SSP) for recharge in the regional phreatic aquifers and riverbeds (GOG, 1996 as cited in Ranade and Kumar, 2004). However, this was never considered in the planning of SSP. Moreover, unprecedented costs and benefits are never considered, as revision of the cost-benefit analysis after many years of project completion is not a general practice (see Biswas and Tortajada, 2001).

\section{THE BASIC PREMISE}

The authors take the position that the criteria used for defining large dams are not true reflections of the socio-economic and environmental concerns prevailing in developing economies, and therefore are not relevant. Food security and water security are extremely important concerns for these economies; submergence of productive land is a big concern, given the poor access to arable land; but not so much the engineering challenges posed by dam height.

The definitions based on such poor criteria often invite unprecedented reactions from environmental lobby worldwide to subject dam building proposal to stringent environmental scrutiny, and to revise benefitcost (BC) calculations to incorporate the social and environmental costs. The authors argue that while there has been a lot of advancement in the recent past in the $\mathrm{BC}$ calculations of dam projects, the methodologies still fail to capture the social and environmental benefits that are likely to be accrued in future. Some such benefits are drinking water security, groundwater recharge, reduced cost of energy for pumping and so on. Often, dam builders inflate certain components of the benefits and under-estimate certain cost components, to pass the scrutiny of national and international environmental agencies. In the process, little attention has been paid to look at alternative ways of designing dams.

\section{OBJECTIVES OF THE STUDY}

The major objectives of this paper are as follows: 1] to discuss the criteria used by various national and international agencies in defining large dams, and identify their limitations in the context of developing countries; 2] to evolve meaningful criteria for defining large storages, which adequately integrates the growing social and environmental concerns associated with dam building; and, 3] identify the gaps in the current cost-benefit calculations, and set out new objectives and criteria for evaluating impacts of large dams in developing economies. 


\section{LARGE DAMS: HISTORY, DEFINITIONS AND RECENT TRENDS}

\subsection{Definitions of Large Dams}

Numerous definitions are available of large dams, each serving different purpose and objectives, and thus, based on different criteria. The U.S. Fish and Wild Life Service, under its Dam Safety Programme has adopted following criteria for defining dams as small, intermediate and large dams (www.fws.gov). According to them, small dams are structures that are less than $40 \mathrm{ft}$ high or that impound less than 1,000 acre-ft of water; intermediate dams are structures that are 40 to $100 \mathrm{ft}$ high or that impound 1,000 to 50,000 acre-ft of water; and large dams are structures that are more than $100 \mathrm{ft}$ high or that impound more than 50,000 acre-ft of water.

The Central Water Commission (CWC), India in its guidelines for safety inspection has given different definitions of dams on the basis of means of classification such as size, gross storage and hydraulic head (CWC, 1987). Against this, the Planning Commission of India has categorised all reservoirs as large, medium and small irrigation schemes on the basis of the area irrigated. According to the Planning Commission a large irrigation project is the one designed for irrigating more than 10000 hectares (ha) of land.

The most recent, yet widely accepted definition of large dams is given by the ICOLD. The ICOLD defines a large dam as one having a wall higher than $15 \mathrm{~m}$ from the lowest general foundation to the crest. However, even dams between 10-15m in height could be classified as large dams if they satisfy at least any one of the following criteria (Rangachari et al., 2000). First: the crest length is more than $500 \mathrm{~m}$. Second: the reservoir capacity is more than one MCM. Third: the maximum flood discharge is more than $2000 \mathrm{~m}^{3} / \mathrm{s}$. Forth: the dam has complicated foundation problems. Fifth: unusual design. The ICOLD definition has dam height as the major criterion for defining a large dam. Since this definition has been widely accepted, all world dams are evaluated on the basis of this definition.

\subsection{A brief history of dam construction, ideologies, and investments on dams in India}

Right up to the 1970s, large dams were seen as the synonym for development and economic progress. Dam-building reached its peak between 1970 and 1980, when an average of two to three new large dams per day were commissioned. Table 1 provides statistics of large dams in India based on ICOLD data.

Table 1: Large Dams in India

\begin{tabular}{|c|c|c|c|c|}
\hline \multirow[b]{2}{*}{$\begin{array}{l}\text { Sr. } \\
\text { No. }\end{array}$} & \multirow{2}{*}{ Period } & \multicolumn{3}{|c|}{ Number of Large Dams } \\
\hline & & $\begin{array}{c}15 \mathrm{~m} \text { and more } \\
\text { high }\end{array}$ & 10 to $14 \mathrm{~m}$ high* & Total \\
\hline 1. & Up to 1900 & 32 & 13 & 45 \\
\hline 2. & $1901-1947$ & 135 & 127 & 262 \\
\hline 3. & 1948-1970 & 489 & 254 & 743 \\
\hline 4. & $1971-1990$ & 1564 & 1066 & 2630 \\
\hline 5. & $1991-2001$ & 265 & 82 & 347 \\
\hline 6. & Data not available & 434 & 174 & 608 \\
\hline 7. & Total & 2919 & 1716 & 4635 \\
\hline
\end{tabular}

* It includes dams whose height is not known.

Source: Data derived from the World Register of Dams, (2003), ICOLD 
These figures of number of large dams in India obtained on the basis of height can be extremely misleading. For instances, the first 2919 dams create a storage space of 296.29 BCM, with a mean storage space per dam to the tune of $101.5 \mathrm{MCM}$. Whereas, the rest 1716 dams put together create a storage space of 6.29 BCM only, with a mean storage space per dam to the tune of 3.65 MCM. So, these are not really large dams in any sense.

Further, the total storage created by all large dams in India is only 302.58 BCM, with a mean storage capacity of $64.28 \mathrm{MCM} / \mathrm{dam}$. This however, does not mean that these dams actually store and provide that much water. The reasons are many. First: many large dams in India do not get sufficient storage, due to inadequate inflows from their catchments, whereas on the other hand, may reservoirs capture and release more than their storage capacity as inflows are received at the time of release of water. Second: the figures of storage capacity are of gross storage, and not live storage. The current total live storage capacity of reservoirs in India is only $214 \mathrm{BCM}$, and for many reservoirs, it is reducing due to silting as per recent sedimentation and siltation studies (Thakkar and Bhattacharyya, 2006, based on State Reservoir Survey data) ${ }^{3}$.

Now, let us look at the figures for United States. The country has 16,383 dams which are listed in the national dams register, which includes small dams as well, or dams having height much less than $10 \mathrm{~m}$. Of these 16383 dams, only 1735 dams have height more than $15 \mathrm{~m}$, and they put together create a storage space of 140.14 BCM, with a mean storage space per dam to the tune of $80.8 \mathrm{MCM}$. But, interestingly, the rest 14,648 dams put together can provide a total storage space of 342 BCM, with a mean storage per dam to the tune of 23.3 MCM (source: the authors' own estimates based on US national dams register). This means, the dams having height less than $15 \mathrm{~m}$, including those having height much lower than $10 \mathrm{~m}$, are very important storage systems for US, as not only the total storage volume exceed that of large dams, but also the mean storage volume per dam is also quite significant.

In Australia, the mean storage provided by a large dam is $176.7 \mathrm{MCM}$ (source: authors' own estimates based on data provided in Natural Heritage Trust, 2000). In nutshell, though India appears to be a champion in terms of building large dams, the actual figures of the water storage potential created by large dams is nowhere near that of countries like United States, which have less number of large dams.

\subsection{THE DAM CONTROVERSY: UNDERLYING ASSUMPTIONS AND GENESIS}

The 4635 large dams in India are either of height above $15 \mathrm{~m}$ or fulfil any other criteria set by ICOLD. With the kind of technical excellence achieved in the field of civil engineering and structural design, constructing a dam of $15 \mathrm{~m}$ height or a dam with unusual design or difficult foundation is not a big challenge any more. Besides, criteria such as unusual design or difficult foundation have not much to contribute towards the environmental problems or achieving the targets of irrigation or economic growth. The arguments of anti-dam activists become forceful when they simply magnify the "negative impacts" of some very controversial dams with this large figure and project that as the cumulative effect of all large dams.

Any average number derived from a select few well-known or controversial dams on attributes such as irrigated area against submerged area, the BC ratio or number of people displaced against the number of people benefited should not be blindly extrapolated to get the cumulative effect of all the dams, classified as "large" by ICOLD. The primary reason for this is the complex factors- physical, climatic, technical/engineering, social, environmental, ecological and political-, which govern the above said attributes of dams, differ from case to case. Braga et al. (1998) points out the danger in using simple indices such as area submerged per MW of electricity generated or number of people displaced per MW of power generated in the context of hydropower dams in Brazil, as according to them they ignore the benefit from multiple use of water. Unless relationships and trends are established on the basis of a large database, it would be difficult and often dangerous to draw inferences on any of those. Establishing such trends between the generally known attributes of dams, and the attributes of social and environmental significance is what we would achieve in the subsequent sections.

\footnotetext{
${ }^{3}$ According to the data cited by the authors, the average live storage loss for 23 reservoirs surveyed was $0.91 \%$ per annum. In nutshell, the actual storage in these dams which can be diverted would be even less.
} 
Should the sheer number of large dams really send warning signals on the magnitude of the costs being paid by the society for the negative consequences on communities and the environment? To answer this question, it is crucial to know the relevance of the criteria used for classifying dams as "large". Here it is important to mention that most of the criteria for classifying dams as large or small evolved at times, when large dam building continue to pose major engineering challenges to the humanity ${ }^{4}$. These criteria never tried to capture the social and environmental imperatives of building dams. The driving force behind this analysis is the strong belief that the controversy of environment and mainly of displacement is critically rooted in the way large dams have been defined in the past, and therefore really need a re-look, especially in the wake of growing social and environmental concerns of building "large dams".

None of the definition mentioned above, including that of ICOLD, is universally applicable. The reason is that different physical attributes of a dam, such as height, storage volume, and submergence area have different implications, which again is likely to change with dam location. So, any one component cannot be generalized to measure the various impacts generated by dams. When the impacts of dams are measured on the basis of ICOLD definition, ultimately it is only the dam height which is being considered ${ }^{5}$. But height does not always have direct relationship with the factors like environmental impacts, displacement or even with total storage volume and submergence area.

Normally, dam designers use the storage-elevation-area curve to determine the appropriate height of the dam and spillway capacity etc. Depending on the topography of the location, the storage-elevation-area relationships would change. In a deep gorge, the area under submergence of a high dam having a large storage volume may be very low. For example: Idukki dam, which is a double curvature arch dam, located in a deep gorge in Idukki, Kerala, India having a height of $555 \mathrm{ft}$, may not have submerged much area. But its storage volume is 2,000 MCM. An analysis of the data of 9,878 dams from ICOLD's World Register of Dams shows that the volume of water stored impounded by a dam is not a function of its height (Figure 1).

Figure 1: Dam Height Vs Storage Volume

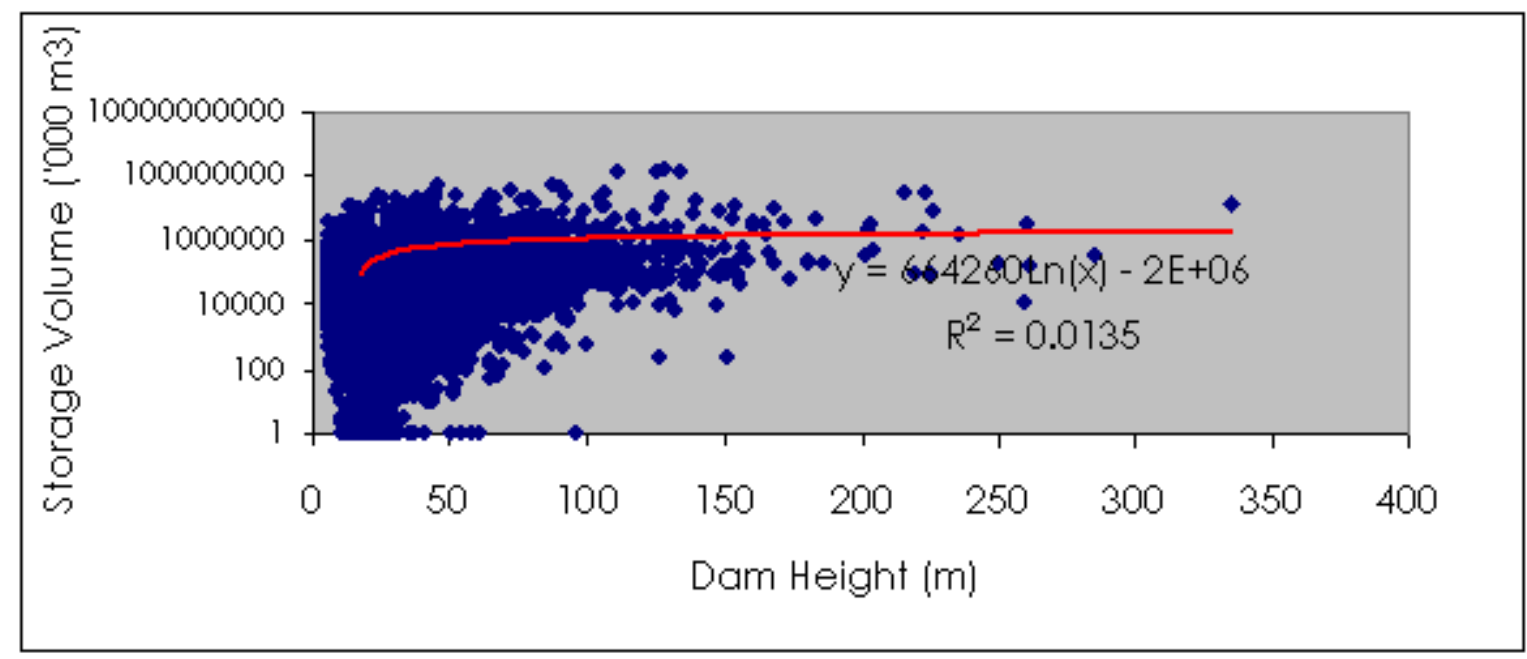

Further analysis with ICOLD data shows that the area of land submerged by the reservoir, which has implications for both environmental and social impacts, such as the number of reservoir affected people and deforestation, and loss of flora and fauna, is not a function of dam height (Figure 2). While it is well known that

${ }^{4}$ Larger height meant greater foundation stresses and forces in the main body of the dam, posing geo-technical challenges. Greater storage meant greater risk for people living in the downstream. Larger spillway discharge meant greater design challenges.

${ }_{5}$ Other secondary criteria such as crest length, dam foundation or unusual design have no bearing on dam impacts in this fast developing world of technology, nor can reservoir capacity or flood discharge capacity logically substitute the dam height criteria. 
the dam storage volume varies with elevation (height of the dam), which has to do with the topography or the catchment characteristics, the relevance of the above analysis is that it shows very clearly that they vary drastically from location to location.

Figure 2: Dam height vs Reservoir Area

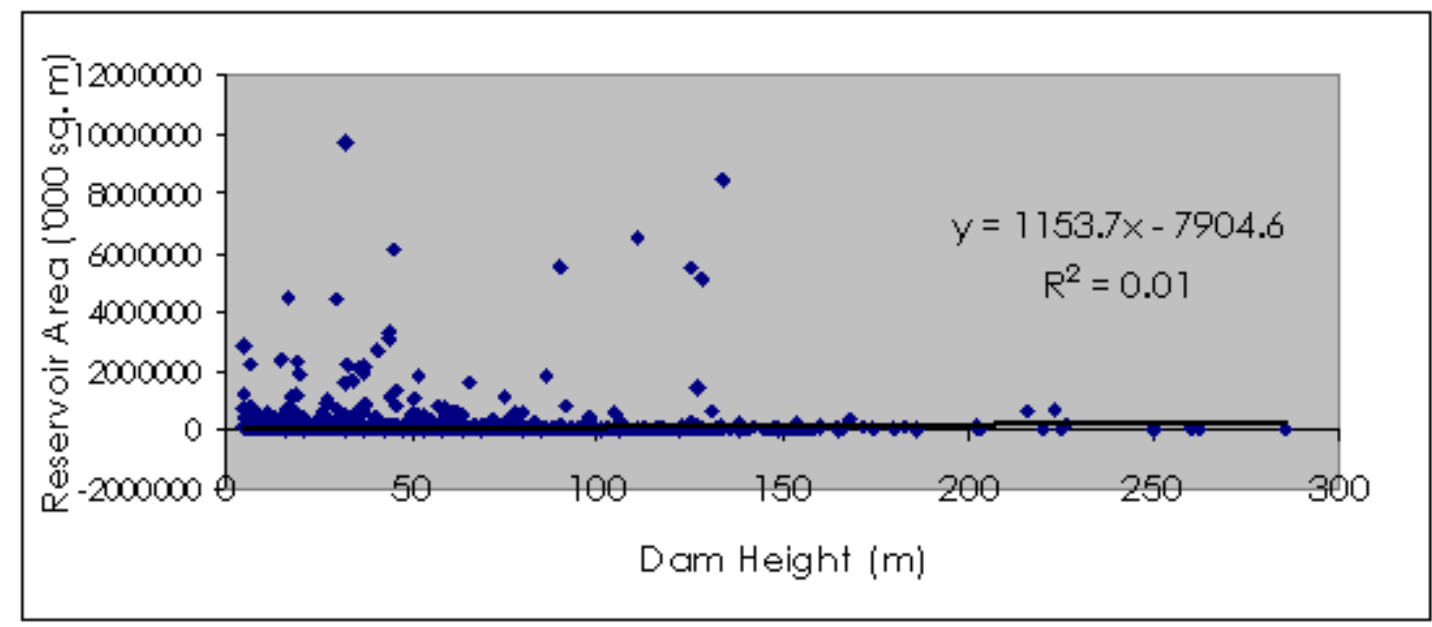

The results emerging from the foregoing analysis had two major implications. First: the concerns expressed by or protests made by environmental groups, world over, over engagement of poor and developing countries in dam building on the basis of the sheer number of large dams are ill-targeted. Second: the criteria currently being used by dam builders and global agencies dealing with large dams such as height and storage volume are not true reflections of the challenges dam builders pose in an era of growing social and environment concerns.

Of the total 4635 large dams of India, with height more than $15 \mathrm{~m}$ or storage volume higher than 1 MCM, 2431 (more than 50\%) are built on local streams. Under such circumstances, some of them might be tank systems, with large surface area, whereas some others might be really big dams with large height and storage. Also, it is likely that they are constructed under various small scale irrigation development schemes to achieve benefits at the local level. Thus, one needs to see whether these storages are created by dams or tanks to analyse their environmental impacts. Moreover, locally initiated water harvesting moves or even small scale irrigation schemes are usually not facing the problem of displacement, and so their negative social impacts are also nil or very limited. In that case more than $50 \%$ of India's large dams are socially and economically rewarding with minimum environmental cost bearing. In fact, their presence might have contributed towards growth of vegetation, fisheries and water security.

\section{OBJECTIVES AND CRITERIA FOR ASSESSING LARGE DAMS}

\subsection{Objectives and Criteria for Classifying Large Dams}

The second set of questions we are confronted with is: what should be the different criteria and considerations involved in classifying dams as small and large so that they are true reflections of the engineering, social and environmental challenges dams pose? On the first question, we have seen that the height of the dam, a major physical criterion used for classifying dams as large and small, does not have any bearing either on the area that dams submerge, or the storage that dams create. Actually, the area submerged by dams has implications for the environmental consequences of reservoir projects. The storage created by dams has implications for the safety hazards they pose, and the hydrological and socioeconomic impacts.

That takes us to the question of what should be the ideal criteria for classifying large dams. Area submerged by dams is a good indicator of the potential ecological damages dams can cause, though the actual 
ecological consequences would depend on several factors such as the nature of the eco-region where the dam is located. Such data are easily available for existing reservoirs, or can be generated for the reservoirs that are being planned. But, does that reflect some of the negative social impacts dams can cause? In that regard, one of the biggest challenges developing countries are confronted with today is to minimize the human displacement by dams, thereby minimizing the human sufferings. This is a major issue because of the position taken by antidam activists that complete rehabilitation of oustees is impossible (see Fisher, 2001). Hence, choosing a physical criterion which adequately captures the two altogether different dimensions of a complex problem caused by dam building becomes all the more important.

Such a criterion would also help quickly and roughly assess the magnitude of displacement that a reservoir project can cause. The anti-dam activists around the world have been using several different estimates of "displacement" to build their case against dams. The following paragraphs illustrate this problem of how inadequate data create misinformation about an issue as vital as displacement. By identifying the right kind of criterion, which uses measurable indicators, for deriving the statistics of large dams also helps us assess the magnitude of problems large dams pose in any country, using data on such indicators.

Global estimates of the magnitude of impacts show that 40-80 million people were displaced by dams (Bird and Wallace, 2001). In case of India, no authentic figures are available for dam-induced displacement. Whatever numbers are available, are derived largely from some rough calculations using simple norms. Fernandes et al., (1989) claimed that India had 21 million people displaced by dams. Some years ago, the then Secretary, Ministry of Rural Development, Government of India, unofficially stated that the total number of persons displaced by development projects in India are around 50 millions, and around 40 millions of them are displaced only by dams.

Some other estimates are based on average displacement per dam. After a study of 54 dams, the Indian Institute of Public Administration (IIPA) concluded that the average number of people displaced per dam was 44,182. Roy (1999) multiplied this figure with 3300 dams in India (CWC estimates, as cited in Roy, 1999) and received the figure of 145 million. Since she felt this figure is too large, she took an average of 10,000 persons displaced per dam, and reached to the figure of 33 million people displaced by dams. Singh and Banerji (2002) have compiled the displacement data of 83 dams with the aggregate of 2,054,251. The list covers dams constructed in the year of 1908 as well as many dams under construction. Based on the submergence area of these 83 dams the authors have estimated an average 8,748 ha land under submergence and the average displacement per ha as 1.51. While multiplying these two average figures with the total numbers of dams of 4291 (as given by CBIP, as cited in Singh and Banerji, 2002), the authors derived the astounding figure of 56,681,879 persons displaced by dams. The authors mention this as a clear overestimation.

Let us analyze the flaws in the estimates which form the basis of many of the arguments against dams. As per the National Register of Large Dams in India there are 1529 large dams in the state of Maharashtra (CWC, 1994). The ICOLD figures put a figure of 1700 dams in the state. If we adopt Roy's estimates of 10,000 persons displaced by a large dam, Maharashtra alone should have displaced between 15.3 and 17 million people. It is most unlikely that such a large population in one state has no visibility. Looking at India's poor track record of rehabilitation, majority of these displaced people might be facing poverty and impoverishment. On the contrary, Maharashtra stands next to Kerala, the state which stands at top on human development indicators (Source: UNDP, 2006).

One of the major limitations of these estimates are that majority of them are derived from the average figures of displacement calculated per dam, and are multiplied with the total number of dams. The figures offered by CWC (1994), CBIP (1987, 1998) and World Register of Large Dams (2003) were on the basis of the total number of large dams, based on ICOLD's definition. Thus, all the estimates of displacement have the inbuilt assumption that dam height influences displacement. This is a wrong perception that higher dams cause larger displacement, whereas it is true that the increase in height of a dam at a specific location would increase the area under submergence and displacement.

It is a truism that theoretically, the population displaced would be largely determined by the submergence area and the population density of the region under consideration. But, still it is important to know whether a 
strong relationship really exists at the operational level between the land area under submergence and population displaced. This is in view of the wide variation in population densities in countries like India from region to region. The following figure supports the argument that it is a good indicator. It is based on our analysis of 156 large dams in India. It shows that the number of people displaced by dams increases linearly with increase in submergence area. Submergence area explains displacement to the tune of 58\% (Figure 3). The rest could be explained by variation in population density, and its effect on displaced population. This is a high level of correlation and therefore can be used to project the number of people displaced by dams, if we have data on the total area under submergence of all large dams.

Figure 3: Submergencve Area Vs Population Displaced

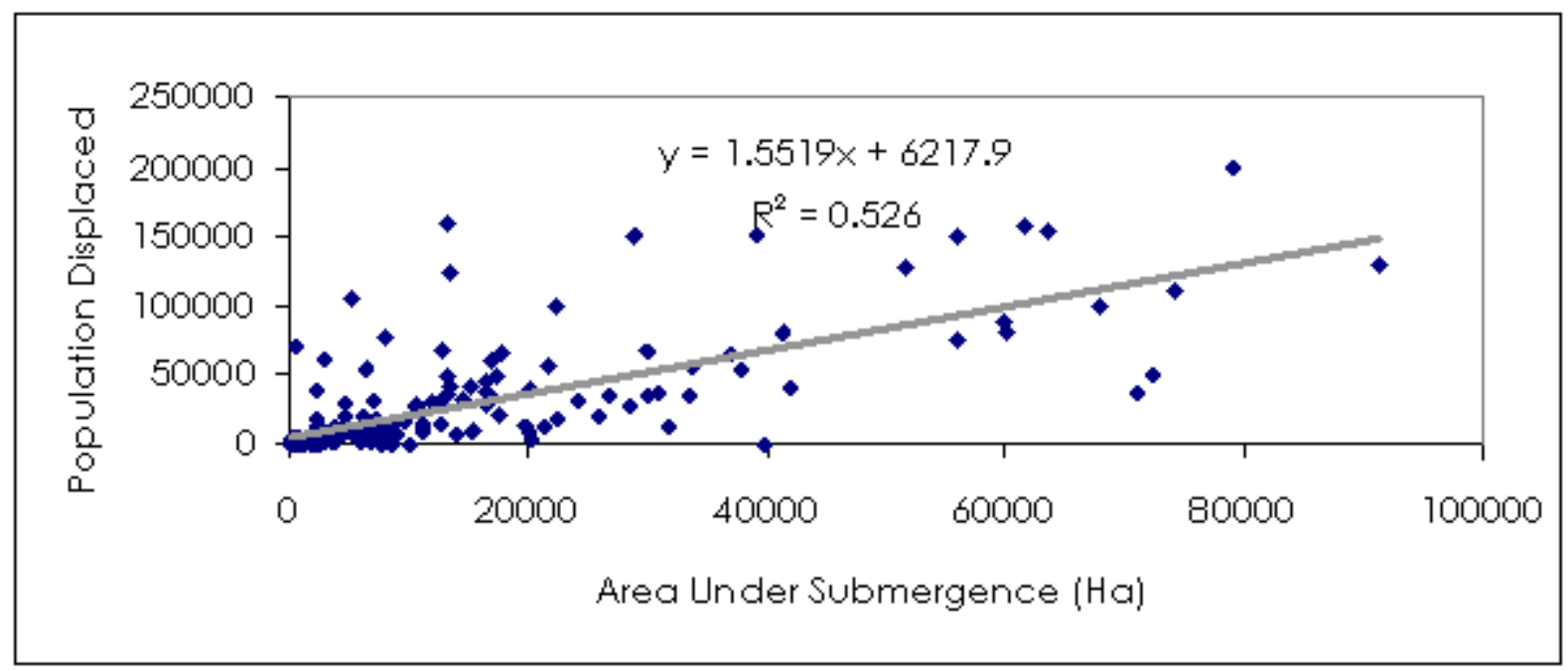

The relationship also means that dam height is mainly location specific, and so does not have direct impact on displacement as we have already seen that dam height does not have any bearing on either storage or submergence area. The graph clearly shows that while 100 ha of submergence can cause the displacement of 150 plus people, what is important to note is that many large dams in India have very low level of submergence. It should be noted here that in a country with a much lower population density (for instance United States), the relationship would be different in the sense that the $\mathrm{X}$ coefficient would be much lower, meaning the number of people displaced by one sq. $\mathrm{km}$ of submergence would be smaller.

Now, the total area submerged by 2933 large dams in India (obtained from The World Register of Dams, 2003) was estimated to be $32,219.25 \mathrm{sq}$. km. The area submerged by 4635 dams was extrapolated to be 49660 sq. $\mathrm{km}(32219 * 4635 / 2933=49660)$. Based on this estimated submergence area and the formula given above, the total number of people displaced by dams was estimated to be 7.845 million people. This is far less than the figures of displaced people provided by earlier researchers.

The main utility of this relationship is that once it is established for a given population density range on the basis of existing database, the number of people likely to be affected by dams in any region having that population density range could be estimated with a reasonable degree of accuracy, if area under submergence is known. A direct approach of estimating displacement based on submergence area and population density in each case would be cumbersome, as it is difficult to get population density data for very small areas which form the reservoir catchments.

Now, it is true that height and storage volume together reflect the engineering challenges posed by dams. So, it can be inferred that a combination of parameters such as height, storage volume and submergence area would give a true reflection of the engineering, social and environmental challenges. Hence, the criteria for classifying large dams should be developed by taking into consideration all these three important parameters. 


\subsection{New Criteria for Evaluating the Performance of Large Dams}

The economic impacts of large dams in India are surmised as negative on the bases of construction cost overruns; poor performance of irrigation systems with heavy wastages due to poor conveyance efficiencies in the distribution system; negative downstream ecological impacts; preference for water-intensive and low water-efficient crops; water logging and salinity in command areas; and the problems of overestimation of benefits resulting from shrinking of command areas due to non-availability of water and ecological problems (see Rangachari et al., 2000). Very few studies really exist which comprehensively evaluate the long term economic and social benefits of large dams.

The criteria selected for impact evaluation also suffer from problems. The same criteria, which were followed for evaluating costs and benefits at the time of planning of the project itself, are used to analyze the dam impacts many years after they become functional (Biswas and Tortajada, 2001). In the process, most of the benefit calculations overlooked major benefits like food security from stable food prices, increased rate of employment in agriculture, improved fisheries, increased access to drinking water supplies, development and growth of processing and marketing units etc. Improved groundwater balance due to return flows from canal irrigation is a social benefit. In many parts of Punjab, well irrigation is sustained due to the continuous return flows available from canal irrigation which add to the recharge (Hira and Khera, 2000).

This is not to argue that large dam projects were free from problems. Many of the dams, especially those built in semi arid and arid regions are over-allocating water from their respective basins as shown by case studies from north Gujarat basins in India (Kumar, 2002). The irrigation agency here was often keen to build over-sized dams, taking the flows of low dependability as the design yield, to inflate the design command and economic benefits. This leads to reduced flows or no flows in the downstream parts of the river in most of the years causing ecological problems (Kumar et al., 2000; Kumar, 2002). But, such problems have occurred more due to inadequate governance of water in river basins, characterised by lack of adequate scientific data for hydrological planning; piecemeal approach to water development; and ad hoc governance of irrigation systems (Kumar et al., 2000).

\subsubsection{Criteria for Evaluating Environmental Impacts}

The arguments against large dams are not founded on scientific assessment of real marginal social costs and benefits. For instance, the long-held position of Narmada Bachao Andolan was that "the social costs of large water development projects cannot be compensated by increased economic benefits accrued from the use of water". They argued that complete rehabilitation of the displaced communities is impossible (Fisher, 2001). They had the deep-rooted belief that cheaper and easier options to large dams exist.

Internationally, such arguments gain a lot of credibility after the concept of virtual water trade was introduced in the early '90s; and later on with small water harvesting options gaining wide acceptance. At least, some of the environmental activists advocate virtual water trade as an alternative to large dams for national food self-reliance. They argue that water-scarce countries should import food grain from water-rich countries. At the same time, the operational level, virtual water flows out of water-scarce regions to water rich regions (Kumar and Singh, 2005). In fact many water-scarce regions in India export agricultural produce worth thousands of million cubic metres of water to regions that are water-rich (Amarasinghe et al., 2004; Singh, 2004). In a similar manner, local water harvesting solutions are found to be having extremely limited scope (Kumar et al., 2006).

This leads us to the point that empirical evaluation of all direct and indirect costs and benefits of dams is inevitable, and the effort should be to minimize the social costs and maximize the returns from large dams, rather than looking at other options. Many international donors have also come out with criteria for evaluating costs and benefits of large dams, which involve stringent environmental criteria. Environmental impact assessment has been made mandatory for all World-Bank assisted dam projects in the world. But, the underlying premise in EIA is that all the environmental impacts associated with large dams are negative. The positive environmental effects of large dam projects such as impact on the local ecology and climate are hardly examined (Kay et al., 1997). 
During the past couple of decades, there were significant advancements in the methodologies for evaluating costs and benefits of dam projects that is now capable of evaluating all future costs and benefits, including those which are social and environmental. But, much less have been the advancements at the conceptual level in clarifying what should be considered as positive effect or benefit and what should be considered as negative effect or cost. This has led to very unbalanced and biased assessment of reservoir projects. We will discuss these issues in the following paragraphs.

One of the strongest criticisms against large reservoir projects by environmentalists was water-logging and salinity problems they can cause in command area. Part of the reason is that world-wide, nearly $50 \%$ of the reservoir projects serve the purpose of irrigation. This has been an issue in many canal command areas of northern and north-western India and Pakistan Punjab. But, dramatic changes in agriculture in countries like India and Pakistan during the past 2-3 decades had converted some of these challenges into opportunities. With increasing groundwater draft for agriculture, which happened as a result of advancement in pumping technologies, massive rural electrification, and subsidized electricity for well irrigation, water-logging is becoming a nonissue in many canal command areas. In Indian Punjab, which is widely cited in literature as basket case of illeffects of canal irrigation, the area under water-logging and salinity had actually reduced (Hira and Khera, 2000). One reason for this is increased dependence of farmers on groundwater. In Gujarat, northern region that is to receive Narmada water experiences groundwater mining. Hence, the threat of rising water levels due to induced recharge from canals does not exist (Ranade and Kumar, 2004).

While water-logging and salinity, and downstream ecological damage are much for people to identify, recognize or feel, the un-intended positive impacts such as drought proofing; drinking water security in rural and urban areas; and increased biomass availability in canal command areas through energy plantation; increased inland culture fisheries due to year-round access to water, though felt, were less talked about, and often less attributed to the dam/reservoir construction. Their performance is not evaluated in relation to number of job these dams create in rural areas; or the fishery production or the number of people benefited by drinking water sector, which are in the domain of different agencies.

Let us now examine the unforeseen benefits. Almost all major dams in the world are constructed for hydropower (Altinbilek, 2002). In many regions of the world, especially in Africa and Asia, the hydropower potential is huge and mostly untapped. Whereas globally, nearly $19 \%$ of all electric power is generated is from hydropower, which is one of the cleanest powers in the world. That said the greatest environmental benefit of pursuing hydropower as an alternative renewable source of energy to the conventional route of burning fossil fuel had found place in the discussions on multi-purpose dams.

Ideally, the negative externalities created by thermal power on the environment could be treated as the positive externality that hydropower generation creates on the society. So, a kilowatt hour of energy produced from hydropower plant should give an additional benefit equal to the cost of environmental damage which a thermal or nuclear power plant would cause for the same amount of power generation, and at higher levels of generation, the marginal social benefits would be high. The future of the energy economy in India and China, the two fast-growing Asian countries, is very much dependent on how they exploit their renewable energy resources like hydropower. Both the countries have vast untapped hydropower potential. In India, most of it lies in north-eastern mountainous region and Western and Eastern Ghats. It would be quite logical to assume that India would see a lot of dam building for hydropower, where the discussions on negative environmental impacts would be less relevant.

The large dams have important role in replenishing groundwater resources. The return flows from canals had played significant role in sustaining tube well irrigation, and thereby agriculture during the years of scarcity (Dhawan, 1990). A recent analysis by Kumar (2007) showed that nearly 5\% of the deep tube wells, $10 \%$ of the dug wells and $5 \%$ of the shallow tube wells in India are located in canal command areas. Induced recharge from canals control groundwater mining for irrigation in many arid and semi arid areas of India, thereby preventing incidence of well failures. As Ranade and Kumar (2004) notes, such impacts are likely to be significant in semi arid north Gujarat, which is experiencing groundwater mining, and which is to receive Narmada water for irrigation. As Kumar (2007) notes, without the return flows from canals, the extent of groundwater mining in Indian Punjab would have been far more serious. 
Unlike other parts of the world, where many large reservoirs are earmarked for water supplies, many large reservoirs in India were built primarily for irrigation. But, India's National Water Policy has given first priority for drinking water over irrigation and industrial demand. During droughts, water from irrigation reservoirs gets earmarked for drinking water supply in rural and urban areas. But, the role of large dams in ensuring drinking water supplies and thereby social security in water-scarce regions is less appreciated. Sardar Sarovar Project in Western India, for example, is expected to make a major dent in the rural and urban drinking water needs of 9,663 villages and 137 urban centres. Without the Sardar Sarovar project, the drinking water situation in these drought-prone areas would have been precarious, in the absence of any sustainable source of water to meet the basic requirements (Talati and Kumar, 2005). As many cities and towns are running out of water, due to permanent depletion of local groundwater, many dams originally meant for irrigation are now supplying water for domestic consumption.

While NGOs, which advocate local alternatives in water management, especially in managing drinking water supplies, had fiercely opposed regional water transfer from Narmada to Saurashtra and Kachchh on cost grounds, they failed in setting up demonstration of such alternatives, which are effective in both physical and economic front (Kumar, 2004).

\subsubsection{Criteria for Evaluating Ecological Impacts}

The arguments about downstream ecological impacts of dams concern potential reduction in lean season flows after impoundment and the environmental stresses they induce (Smakhtin, Revenga and Döll, 2004). But, in practice, regulatory reservoirs could be used to mimic natural flows that are needed for ecosystem health. For instance, in Narmada river basin in central India, large stretches between Indira Sagar dam and Sardar Sarovar dam, the flows are going to be regulated, and as a result lean season flows would be more than in the natural case.

Map 1, Showing the Sardar Sarovar Reservoir, Narmada Main Canal and Rivers of North Gujarat

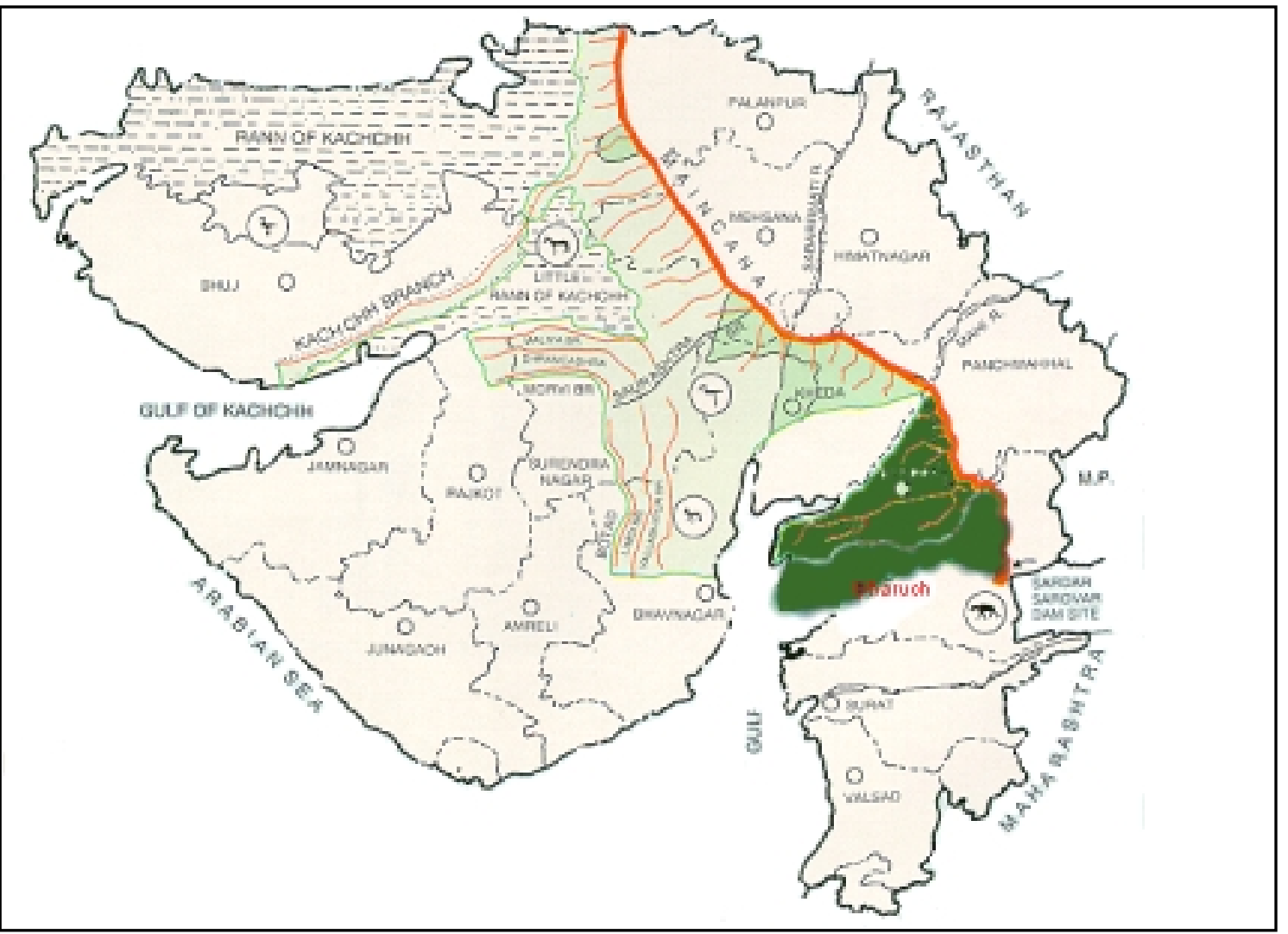


The more immediate, positive ecological impacts would be accrued in water-starved regions where surplus flows from reservoir can be diverted for ecological uses. The gigantic water transfer project in China involving bulk transfer of water from the water-rich Yangtze river basin to seven provinces in the water-scarce north China plains could benefit more in terms of providing water for ecological flows in Yellow river and meeting drinking water needs of big cities like Beijing. Yellow river had already dried up due to heavy diversion of water for irrigation in the agriculturally productive plains, and no water reaches the end of the river.

In Narmada basin, the Sardar Sarovar reservoir being the terminal reservoir, it can receive all surplus flows from the reservoirs upstream. These surplus flows will be significant so long as upstream dams are not built (Gupta and Kumar, 2006). This water can be diverted through the Narmada Main Canal which runs north, cutting through in rivers in north and central Gujarat viz., Sabarmati, Watrak, Shedhi, Meshwo, Khari, Rupen, Sipu and Banas. Those stretches of the rivers, which the canal intersects, do not carry any flows during lean season even in wet years (see Map 1). They can hence receive the excess flows being diverted from Sardar Sarovar reservoir, which will provide for riverine ecosystems and also recharge the over-exploited alluvial aquifers of north Gujarat (Ranade and Kumar, 2004). This is already being practiced in rivers of Central Gujarat. North Gujarat aquifers have high levels of salinity and fluoride, at many places deteriorating drinking water supply situation, with major public health consequences (Kumar et al., 2001). The induced groundwater recharge can help to improve the quality of water by diluting the mineralized water in the aquifers, along with improving riverine ecology (Kumar and Ranade, 2004).

\subsubsection{Criteria for Evaluating Social and Economic Benefits}

There are problems in the way performance of dams is being evaluated by global interest groups. For instance, the criteria selected by the WCD report for evaluating dams are completion on time and completion within budget (Perry, 2001). Such technical and financial criteria often provide unfair treatment to large dams. According to Perry (2001), criteria such as food availability, food security, food prices or even resettlement success are the right indicators to measure the economic performance of dams. Food security is an important water management goal for many water-scarce countries including India and China (Kumar, 2003; Kumar and Singh, 2005). Food security is the central goal of constructing around 90\% large dams in India and other parts of Asia, and the ratio is of $70 \%$ in Africa. As per ICOLD data, worldwide, nearly $48 \%$ of all large dams in the world were built for irrigation. Still, the positive externalities induced by improved food security were less articulated.

According to Bhalla and Mookerjee (2001), the total irrigation expenditure on major and medium irrigation schemes since independence in India has totalled Rs. 187,000 crore at 1999 prices. Against this the total agricultural output in 1998-99 was close to Rs. 500,000 crore. After Bhalla and Mookerjee (2001), depending on the assumptions one makes for how much of the total investment is allocated for big dams (whether $100 \%$ or $75 \%$ ) and depreciation rates (3 to 5\%), one obtains IRRs in the range of 3 to $9 \%$. This is the direct economic benefit.

The positive externality effects of dam building should be added to it to get the social benefits. The benefits accrued from such positive externalities of increased food security benefits, should be assessed in terms of the opportunity cost of not producing that additional food internally, i.e., the cost of importing food. This is nothing but the import price of food grains minus the price at which it is available in the local market. In order to examine how the Asian giants, China and India influence international food prices under scenarios of rising cereal imports due to increasing meat consumption, a response to income rise and declining domestic production due to degradation of natural resource base, an IFPRI study used IMPACT (International Model for Policy Analysis of Agricultural Commodities and Trade) to simulate a scenario of increased food imports by India to the tune of 24 million ton and China to the tune of 41 million ton in 2020. The model showed an increase in international wheat and maize prices to the tune of $9 \%$ and rice prices to the tune of 26\% (Rosegrant et al., 2001).

If we consider that half of the additional food grain production of 94 million ton produced from irrigation in India since 1950s is from large dams (Perry, 2001), and that we decide to compensate the reduced production in the absence of large dams through food imports, and that prices would go up by just US\$20/ton 
(nearly $10 \%$ of the current price), this would mean a total additional burden of Rs. 42.30 billion rupees annually for the imported portion alone. This is more than $0.10 \%$ of India's GDP. If we assume that the current domestic cereal prices are close to import prices, the lower price consumers pay (say by US\$20/ton) is the impact of domestic production of cereals on the food prices or the cost to the consumers, and therefore can be considered as a positive externality effect of large dams. This whooping opportunity of cost importing cereals itself seems to justify the large investment India had made in the irrigations sector. Such benefits should be added to the direct economic benefits to get the real social benefits of dam-building. This amount is the subsidy government provides to the people by avoiding food imports and keeping the cereal prices in the local market under control.

\subsubsection{Internalizing the Negative Externalities in Project Costs}

The irrigation bureaucracies in poor countries in Asia and Africa show unwillingness to include the negative externalities as part of the project cost as they do not like to transfer those costs to the water users, due to the fear that it would bring down the demand for water, and as a result would make BC ratios very unattractive. Instead, the practice is to bundle all such costs, and come out with a compensation package for the affected people once the project is cleared after the scrutiny for economic viability by the donors.

This myopic tendency can be explained by the fact that the reduction in benefit resulting from the decision to cut down the size of the project to minimize the negative effects on society would be disproportionately higher than the cost reduction. This can adversely affect $\mathrm{BC}$ ratios. Hence, in an effort to get donor funds, the size of the project is stretched beyond the point where the net benefit becomes equal to net social costs through exclusion of the negative externalities in cost calculations. This creates social ill-fare due to inequity in distribution of project benefits. In other words, those who get the benefits do not bear the costs. Since the project agencies do not earn sufficient revenue from the services it provides, adequate attention is not paid to compensating those who are adversely affected by the project. Such tendencies have also helped dam builders in inflating the net benefits of the projects.

If the donors make it mandatory for the dam builders to include the economic value of negative externality effects in the project cost, it would have the following desirable consequences. First: the agencies would try and come out with innovative designs to reduce the marginal social cost of water development. Second: they would try and improve the quality of provision of water to raise the marginal value of the water. By doing this even with lower level of development, the net social welfare from large dam projects could be enhanced.

\subsubsection{Summary}

In nutshell, the criteria for evaluation of costs and benefits of dams need to be made more comprehensive taking into account all possible externalities associated with ecological, environmental, economic and social benefits that dams are expected to accrue. For developing economies, such benefits include: i] environmental benefits due to improved groundwater recharge through canal return flows, particularly in arid and semi arid regions, greater drinking water security in drought-prone areas, and availability of clean energy; ii] economic benefits due to additional well irrigation possible with augmented groundwater and reduced well failures; iii] ecological benefits from increased flows in the downstream areas of highly degraded rivers; and iv] improved regional and national food security that come from lowering of food prices and making it accessible to most people. On the other hand, the negative externalities a large dam project creates should be built in the project cost, and be transferred to those who benefit from large dams in terms of additional price they pay for the services.

\section{CONCLUSIONS}

We have investigated mainly two issues in this paper. 1. Do the current technical criteria used in classification of dams as "small" and "large" adequately capture the magnitude of likely negative social and environmental impacts they can cause? If not, what should be the criteria for classifying dams for them to be 
true reflections of the engineering, social and environmental challenges dams pose? 2. Are the objectives, criteria and parameters currently used to evaluate the costs, and benefits of large water impounding and diverting systems, sufficient to make policy choices between conventional dams and other water harvesting systems or groundwater based irrigation systems? Or what new objectives and criteria, and variables need to be incorporated in the cost-benefit analysis of dams so as to make it comprehensive?

The criteria used by ICOLD for classifying large dams, such as height and storage capacity, are not sufficient to capture the potential negative environment and social consequences, for which large dams face opposition from environmental lobby around the world. Analysis of data for 13,631 large dams around the world shows that the height of dam does not determine the storage volume, which, in a way, implies the safety hazards posed by dams. Further analysis using data for 9878 large dams shows that height does not determine the amount of land submerged by reservoirs, which implies the negative social and environmental impacts dams can cause. The use of such criteria results in over-estimation of negative impacts like displacement, leading to over-reaction from environmental lobby against large dams.

While India appears to be a world champion in building large dams in terms of number of large dams built so far, the actual storage being achieved by these dams is nowhere comparable to those in United States and Australia. Therefore, classification based on dam height neither indicates the potential benefits of dams.

Analysis of data for 156 large dams in India shows that the number of people displaced by dams is a linear function of the total area submerged by them. Every one sq. km of area submerged by large dams in India displaces around 154 people. Using the estimate of 49,660 sq. $\mathrm{km}$ as the area submerged by large dams, the total population displaced by them was calculated to be 7.845 million people. What might change for other parts of the world is the number of people displaced per unit submergence area according to variation in population density. As shown by our analysis, while the area submerged by dams could be an important criterion for deriving more reliable statistics about displacement, the available estimates of dam related displacement in India are gross over-estimates, in an order of magnitude of eight.

Thus, the criteria for classifying dams should be developed on the basis of the three parameters, namely, dam height, storage volume, and submergence area for them to truly reflect the true engineering, social and environmental challenges posed by them.

It is becoming increasingly clear that local water harvesting and virtual water trade options are nonexistent in many countries which need to produce more food. This would compel water professionals to look for ways to minimize the social costs and maximize the returns from large dams. Apart from the economic cost of negative externalities on society in terms of human displacement and ecological degradation, the criteria for evaluating the costs and benefits of dams should involve considerations such as positive externalities associated with larger social and environmental benefits such as stabilizing domestic food prices, reduced carbon emission for energy production, improvement in groundwater replenishment in semi arid and arid areas due to return flows, and social security through improved access to water for drinking. The benefit due to lower food prices from domestic production of 47 million tons of cereals, the approximate contribution of large dams to India's granary, alone would be Rs.42.90 billions.

Water and power development agencies in poor and developing countries are not willing to transfer the additional cost of water provisions due to the negative externalities of dam building, on the beneficiaries of dams. They fear that with increased cost, and therefore with the increased prices users have to pay, the demand for water would come down significantly, making it difficult for them to justify large projects. Such underestimation helps them show higher demand for water and energy from the system, thereby being able to build projects to such sizes where the marginal social cost far exceeds the marginal social benefits, causing negative welfare effects on the society. If the donors make it mandatory for the dam builders to build in the economic value of negative externality effects of dam building into the project cost, the net social welfare from large dam projects could be enhanced. It is argued that such an approach will also increase the pressure on the dam builders to come out with innovative systems design that minimizes the costs, and raise the marginal value of water, thereby raising the net social welfare. 


\section{ACKNOWLEDGE}

Resources for this study was made available from IWMI TATA Water Policy Program to which the first author was associated as a junior consultant.

\section{REFERENCES}

Agarwal, A. and S. Narain (1997), Dying Wisdom: Rise and Fall of Traditional Water Harvesting Systems, Centre for Science and Environment, New Delhi.

Altinbilek, D. (2002) The Role of Dams in Development, International Journal of Water Resources Development, 18 (1).

Amarasinghe, U., B. R. Sharma, N. Aloysius, C. A. Scott, V. Smakhtin, C. de Fraiture, A. K. Sinha and A. K. Shukla (2004), Spatial Variation in Water Supply and Demand across River Basins of India, International Water Management Institute, Research Report 83, Colombo, Sri Lanka.

Athavale, R. N. (2003), Water Harvesting and Sustainable Supply in India, published for Environment and Development Series, Centre for Environment Education, Rawat Publications, Jaipur and New Delhi.

Bhalla, S. and A. Mookerjee (2001), Big Dam Development: Facts, Figures and Pending Issues, International Journal of Water Resources Development, 17 (1) Taylor \& Francis Ltd.

Bird, J. and P. Wallace (2001), Dams and Development- An Insight to the Report of the World Commission on Dams, Irrigation and Drainage, 50. John Wiley \& Sons, Ltd.

Biswas, A. K. and C. Tortajada (2001), Development and large Dams: A Global Perspective, International Journal of Water Resources Development, 17 (1).

Braga, B., O. Rocha and J. Tundisi (1998), Dams and the Environment: The Brazilian Experience, International Journal of Water Resources Development, 14 (2).

Briscoe, J. (2005), India's Water Economy: Bracing up for a Turbulent Future, key note address at the $4^{\text {th }}$ Annual Partners Meet of IWMI-Tata Water Policy Research Program, Institute of Rural Management Anand, 26-29 February, 2005.

CBIP (1987), Large Dams in India Part-I, Central Board of Irrigation and Power, Government of India, New Delhi.

CBIP (1998), Large Dams in India, Part-II. Central Bureau for Irrigation \& Power, Government of India, New Delhi.

CWC (1987), CWC Guidelines for Dam Safety (revised), Central Water Commission, Government of India, New Delhi.

CWC (1994), National Register of large Dams, Central Water Commission. Government of India, New Delhi.

Dam Safety Program Description, Definitions, and Standards. U S Fish and Wild Life Services. http:// www.fws.gov/policy/361fw2.html

Dharmadhikary, S. (2005), Unravelling Bhakra: Assessing the Temple of Resurgent India, Manthan Adhyayan Kendra, New Delhi.

Dhawan, B. D. (Eds.) (1990), Big Dams: Claims, Counter Claims. New Delhi: Commonwealth Publishers.

D’Souza, D. (2002), Narmada Dammed: An Enquiry into the Politics of Development, New Delhi: Penguin Books India, New Delhi. 
Fernandes W., J. Das and S. Rao (1989), Displacement and rehabilitation: An Estimate of extent and Projects. In Fernandes, W., and E. Ganguly Thukral (Eds.), Development, Displacement and rehabilitation, Indian Social Institute, New Delhi (p.p. 62-88).

FAO (2006), The AQUASTAT database. Rome. http://www.fao.org/aq/agl/aglw/aquastat/dbase/index.stm

Fisher, W. F. (2001), Diverting Water: Revisiting Sardar Sarovar Project, International Journal of Water Resources Development, Vol. 17 (1), 303-314.

Glieck, P. H. (1997), Human Population and Water: Meeting Basic Needs in the $21^{\text {st }}$ Century, in R. K. Pachauri and Lubina F. Qureshi (Eds.) Population, Environment and Development. New Delhi: Tata Energy Research Institute. pp. 105-121.

Gupta, S. K. and M. D. Kumar (2006), Dynamics of Inter-Basin Water Transfer: Lessons from Sardar Sarovar Narmada Project, Hydrology Review.

Hira, G. S. and K. L. Khera (2000), Water Resource Management in Punjab under Rice-Wheat Production System, Department of Soils, Punjab Agricultural University, Ludhiana.

Kay, M., T. Franks and L. Smith (1997), Water: Economics, Management and Demand. E \& FN Spon, London.

Kumar, M. D., V. Ballabh and J. Talati (2000), Augmenting or Dividing: Surface water Management in the Water-Scarce River Basin of Sabarmati, Working Paper 147, Institute of Rural Management, Anand.

Kumar, M. D., O. P. Singh and K. Singh (2001), Groundwater Depletion and its Socioeconomic and Ecological Consequences in Sabarmati River Basin, Monograph \# 2, India Natural Resources Economics and Management Foundation, Anand.

Kumar, M. D. (2002), Reconciling Water Use and Environment: Water Resource Management in Gujarat, Resource, Problems, Issues, Strategies and Framework for Action, (report submitted to Gujarat Ecology Commission for the Hydrological Regime Subcomponent of the State Environmental Action Programme supported by the World Bank).

Kumar, M. D. (2003), Food Security and Sustainable Agriculture in India: The Water Management Challenge, Working Paper 60, International Water Management Institute, Colombo, Sri Lanka.

Kumar, M. D. (2004), Roof Water Harvesting for Domestic Water Security: Who Gains and Who Loses? Water International, 29 (1).

Kumar, M. D. and R. Ranade (2004), Large Water Projects In The Face Of Hydro Ecological \& Socioeconomic Changes In Narmada Valley: Future Prospects And Challenges, Journal of Indian Water Resources Society, July.

Kumar, M. D. and O. P. Singh (2005), Virtual Water in Global Food and Water Policy Making: Is There a Need for Rethinking? Water Resources Management, 19: 759-789.

Kumar, M. D., S. Ghosh, A. R. Patel, O. P. Singh and R. Ravindranath (2006) Rainwater Harvesting in India: some critical issues for basin planning and research, Land Use and Water Resource Research, 6 (2006): $1-17$.

Kumar, M. D. (2007), Groundwater Management in India: Physical, Institutional and Policy Alternatives, Sage Publications, New Delhi.

Laurence, P., M. Meigh and C. Sullivan (2003), Water Poverty of Nations: International Comparisons, Kellee University, Wallingford, UK. 
Mc Cully, P. (1996), Climate Change Dooms Dams, Silenced Rivers: The Ecology and Politics of Large Dam, Zed Books, London.

National Inventory of Dams, United States, http://crunch.tec.army.mil/nid/webpages/nid.cfm

Natural Heritage Trust (2000), Water Resources in Australia, A Summary of the National Land and Water Resources Audit's Water Resources Assessment 2000, www.nlwra.gov.au/atlas.

Pearce, D. W. and J. Warford (1993), World Without End: Economics, Environment, and Sustainable Development. (Published for the World Bank), Oxford University Press.

, London and New York.

Perry, C. J. (2001b.), World Commission on Dams: Implications for Food and Irrigation, Irrigation and Drainage, 50: 101-107.

Ranade, R. and M. D. Kumar (2004), Narmada Water for Groundwater Recharge in North Gujarat: Conjunctive Management in Large Irrigation Projects, Economic and Political Weekly, XXXIX (31): pp 3498-3503.

Rangachari, R; N. Sengupta; R. R. Iyer, P. Banergy and S. Singh (2000), Large Dams: India’s Experience, Final Report, prepared for the World Commission on Dams, Secretariat of World Commission on Dams, Cape Town, South Africa.

Rockström, J., J. Barron and P. Fox (2002), Rainwater management for improving productivity among small holder farmers in drought prone environments, Physics and Chemistry of the Earth, 27 (2002): 949959.

Rosegrant, M. W; M. S. Paisner, S. Meijer, J. Witcover (2001), 2020 Global Food Outlook: Trends, Alternatives, and Choices, A 2020 Vision for Food, Agriculture, and the Environment Initiative, International Food Policy Research Institute, Washington D.C.

Roy, A. (1999), The Greater Common Good. Frontline. Volume 16 - Issue 11, May. 22 - June 04Frontline \& Tribeca Internet Initiatives Inc.

Shah, T. and B. van Koppen (2006), Is India Ripe for Integrated Water Resources Management? Fitting Water Policy to National Development Context, Special Articles, Economic and Political Weekly, August 5, 2006.

Singh, O. P. (2004), Water-intensity of North Gujarat's Dairy Industry: Why Dairy Industry Should Take a Serious Look at Irrigation?, paper presented at the second International Conference of the Asia Pacific Association of Hydrology and Water Resources (APHW 2004), Singapore, June 5-9, 2004.

Singh, S. and P. Banerji (2002), Large Dams in India: Environmental, Social \& Economic Impacts. Indian Institute of Public Administration, New Delhi, India.

Smakhtin, V., C. Revenda and P. DÖll (2004), Taking into Account Environmental Water Requirements in Global-Scale Water Resources Assessments, Comprehensive Assessment Report 2, Comprehensive Assessment Secretariat, Colombo.

Sullivan, C. (2002), Calculating Water Poverty Index, World Development, 30 (7): 1195-1211.

Talati, J. and M. D. Kumar (2005) Quenching the Thirst of Gujarat through Sardar Sarovar Project, paper presented at the XII World Water Congress, New Delhi, 22-26 November, 2005.

Thakkar, H. and S. Bhattacharyya (2006), Reservoir Siltation: Latest Studies- Revealing Results, a Wake up Call. Dams, Rivers \& People. www.sandrp.in 
United Nations Development Program (UNDP) (2006), Human Development Report, United Nations, New York.

Verghese, B. G. (2001), Sardar Sarovar Project Revalidated by Supreme Court, International Journal of Water Resources Development, 17 (1): 79-88.

Vora, B. B. (1994), Major and Medium Dams: Myth and the Reality, Hindu Survey of the Environment, The Hindu, Chennai.

Vyas, J. (2001), Water and Energy for Development in Gujarat with Special Focus on the Sardar Sarovar project, International Journal of Water Resources Development, 17 (1): 37-54.

World Bank (2005), Pakistan Water Economy: Running Dry, Report 34081-PK. South Asia Region, Agriculture and Rural Development Unit, Washington D.C.

World Commission on Dams (2000), Dams and Development: ANew Framework for Decision Making. Earthscan Publications Ltd, UK.

World Register of Dams (2003), International Commission on Large Dams. www.icoldcigb.net 